RAND RESEARCH AREAS THE ARTS

CHILD POLICY

CIVIL JUSTICE

EDUCATION

ENERGY AND ENVIRONMENT

HEALTH AND HEALTH CARE

INTERNATIONAL AFFAIRS

NATIONAL SECURITY

POPULATION AND AGING

PUBLIC SAFETY

SCIENCE AND TECHNOLOGY

SUBSTANCE ABUSE

TERRORISM AND

HOMELAND SECURITY

TRANSPORTATION AND INFRASTRUCTURE

WORKFORCE AND WORKPLACE

This fact sheet is part of the RAND Corporation research brief series. RAND fact sheets summarize published, peerreviewed documents.

Corporate Headquarters

1776 Main Street

P.O. Box 2138

Santa Monica, California

90407-2138

TEL 310.393 .0411

FAX 310.393 .4818

(c) RAND 2007

\section{What Progress Is Mississippi Making in Rebuilding Its Affordable Housing Stock After Katrina?}

n August 2005, Hurricane Katrina devastated the coastal regions of Louisiana, Mississippi, and Alabama, inflicting major damage to commercial property, infrastructure, and housing. However, the hurricane's effects were most pronounced in Mississippi, in the coastal counties of Hancock, Harrison, and Jackson.

Immediately after the storm, Mississippi's governor, Haley Barbour, appointed the Commission on Recovery, Rebuilding, and Renewal to determine the extent of the damage and recommend policies to aid the recovery. Following the commission's report, because there remained a need to understand the full extent of the damage and the specific effects on the U.S. Gulf Coast housing market, the RAND Gulf States Policy Institute- a partnership between the RAND Corporation, a nonprofit research organization, and seven Gulf States universities - continued the effort by developing a comprehensive quantitative assessment of both the extent and nature of the damage to the housing stock and the progress that has been made toward recovery.

Key findings include the following:

- Although recovery is proceeding (with building permits issued for 60 percent of storm-damaged units), it has been uneven, being slower in the affordable-housing market sector, slower for un- and underinsured properties, and varying significantly in different communities.

- At the current pace, recovery will take at least another three years, with a total estimated cost of more than $\$ 4$ billion.

- The damage wrought by Katrina compounded a preexisting affordable-housing shortage. Efforts have been made to expand the affordable-housing supply, but the full effects of these measures have yet to be felt. In the meantime, the available supply remains limited - which has likely slowed the overall pace of economic recovery.

- Access to financing appears to be the single most important obstacle to recovery. Many sources of financing exist; however, there are gaps in the funding they provide. Such gaps are most pronounced for the un- and underinsured, households that have suffered major damage to their units, and landlords. Filling these gaps would probably do more to expedite recovery than any other policy action.

- In the short term, there is considerable evidence that the growth in construction capacity has not matched the recovery need. However, over the long term, construction capacity does not appear to be the major constraint on recovery.

- Understandably, the immediate pressures of restoring the housing stock have taken precedence in recovery efforts, but such pressures can conflict with the need to recognize the importance of longerterm mitigation actions. Katrina is not the first devastating hurricane to hit the U.S. Gulf Coast, nor is it likely to be the last.

- Although local officials recognize this tension, they must avoid succumbing to immediate pressures and ensure that they take actions to limit damages from future storms via planning and zoning; enact regulations to encourage mitigation of damages to individuals and their housing through building codes and other measures; and, regionally, take steps to ensure better and faster reconstruction after the next major hurricane. 
This fact sheet is based on Post-Katrina Recovery of the Housing Market Along the Mississippi Gulf Coast, by Kevin F. McCarthy and Mark Hanson, TR-511-OA/MAR/ NAR, 2007, 150 pp., available at http://www.rand.org/pubs/technical_reports/TR511/. The RAND Corporation is a nonprofit research organization providing objective analysis and effective solutions that address the challenges facing the public and private sectors around the world. RAND's publications do not necessarily reflect the opinions of its research clients and sponsors. RAND ${ }^{\circledR}$ is a registered trademark.

\section{RAND Offices}

Santa Monica, CA • Washington, DC • Pittsburgh, PA • Jackson, MS / New Orleans, LA • Cambridge, UK • Doha, QA 


\section{RAND GULF STATES POLICY INSTITUTE}

THE ARTS

CHILD POLICY

CIVIL JUSTICE

EDUCATION

ENERGY AND ENVIRONMENT

HEALTH AND HEALTH CARE

INTERNATIONAL AFFAIRS

NATIONAL SECURITY

POPULATION AND AGING

PUBLIC SAFETY

SCIENCE AND TECHNOLOGY

SUBSTANCE ABUSE

TERRORISM AND HOMELAND SECURITY

TRANSPORTATION AND INFRASTRUCTURE

WORKFORCE AND WORKPLACE
This PDF document was made available from www.rand.org as a public service of the RAND Corporation.

This product is part of the RAND Corporation research brief series. RAND research briefs present policy-oriented summaries of individual published, peerreviewed documents or of a body of published work.

The RAND Corporation is a nonprofit research organization providing objective analysis and effective solutions that address the challenges facing the public and private sectors around the world.

\section{Support RAND}

$\underline{\text { Browse Books \& Publications }}$

Make a charitable contribution

For More Information

Visit RAND at www.rand.org

Explore RAND Gulf States Policy Institute

View document details

Limited Electronic Distribution Rights

This document and trademark(s) contained herein are protected by law as indicated in a notice appearing later in this work. This electronic representation of RAND intellectual property is provided for non-commercial use only. Unauthorized posting of RAND PDFs to a non-RAND Web site is prohibited. RAND PDFs are protected under copyright law. Permission is required from RAND to reproduce, or reuse in another form, any of our research documents for commercial use. For information on reprint and linking permissions, please see $\underline{\text { RAND Permissions. }}$ 